colour) of some of the plants of significant horticultural beauty brought to Great Britain. Part of the collection is still unidentified; but the account seeks rather to portray those species which might attract British gardeners. The genus Meconopsis is perhaps most strongly represented, followed closely by Gentiana, but many other genera are mentioned. Mr. F. Kingdon Ward has also a recent short paper on his war-time explorations in Manipur ( $J$. Roy. Hort. Soc., 73, Pt. 2, Feb. 1948). He noted many interesting plants and confirmed several earlier records by Watts and Clarke.

\section{Natural History of Butterflies}

A 20-PAGE booklet on "Butterfly Migration" by Dr. C. B. Williams, in the "Young Britain" Educational Series of the Daily Mail, has recently come to hand. Simply but effectively written and attractively illustrated, it is a publication with an immediate appeal to young naturalists, if not to older ones also. The photographs of the living insects by S. Beaufoy add to its merits, and the chief facts relative to butterfly migration and what to look for in this field of natural history are clearly presented. Details regarding the various publications in the series are to be obtained from the Daily Mail School-Aid Department, New Carmelite House, London, E.C.4. The present booklet and many of the others are priced at 1s.; some cost a little more, but are excellent value at this low figure.

\section{Archæology of the Missouri Valley}

THE Government of the United States is undertaking a large flood control and development programme in the Missouri Valley, and this will result in the destruction or submergence of many archæo. logical sites which badly need study. Work in the area is a race against time, and "Prehistory and the Missouri Development Program", by W. R. Wedel (Smithsonian Misc. Coll., 107, No. 6), is a summary of what is already known about the archæology, together with an account of a preliminary survey, under the auspices of the Smithsonian Institution, done during the field season of 1946, in order to determine which sites ought to be excavated before they are overwhelmed.

\section{A New Mathematical Journal}

THE Institute for Mathematics and Mechanics of New York University, of which the director is Prof. R. Courant, has now undertaken the production of a new journal entitled Communications on Applied Mathematics, which will appear quarterly. The publishers are Interscience Publishers, New York and London, and the subscription is eight dollars a year. The first number, dated January 1948, contains 99 well-printed pages, on good paper, with several diagrams. Most of it consists of an elaborate investigation of non-linear wave propagation in shallow water and open channels by J. J. Stoker. There is also a shorter paper on free boundaries of an ideal fluid by M. Shiffman. The second number will contain other papers on water waves. It is not intended that the new journal shall deal only with hydrodynamics; later numbers will cover a great variety of topics, including quantum theory, elasticity, aerodynamics, combustion, kinetic theory of gases, and the numerical solution of non-linear partial differential equations. Most of the papers will originate from the Institute for Mathematics and Mechanics of New York University.

\section{International Society of Hematology}

THE International Society of Hematology will hold its bi-annual meeting in Buffalo, New York, during August 23-26. The provisional time-table allows for half-day sessions as follow: general subjects, including radioactive and stable isotopes in hæmatology ; problems and diseases related to the red cells ; problems and diseases related to the white cells; immunohæmatology, $R h-H r(C D E-c d e)$ antigens and antibodies, and hæmolytic anæmias (two sessions); coagulation problems and hæmorrhagic diseases. The chairman of the Programme Committee is Dr. Ernest Witebsky, Buffalo General Hospital, Buffalo, New York. Dr. Eduardo Uribe Guerola, Leibnitz 212, Nueva Colonia Anzurez, Mexico, D.F., is responsible for programme arrangements from South and Central Aimerica, and Sir Lionel Whitby, University of Cambridge, for papers from Europe. All scientific sessions and exhibits will be open to those interested in hæmatology. The secretary of the Society is Dr. Sol Haberman, William Buchanan Blood Centre, Baylor Hospital, Dallas, Texas, from whom further particulars can be obtained.

\section{International Rheological Congress}

Ax International Rheological Congress will be held at Scheveningen (The Hague) during September 21-24. The Congress will consider theoretical problems; fundamental experimental methods; rheological properties of various systems; rheological problems in biology ; and industrial applications. The plasticity of crystallized materials, soil mechanics and geophysical problems will be excluded, since other international congresses will give attention to these subjects during the year. Sectional meetings for the discussion of special subjects will be a feature of the meeting; at these meetings, every speaker will give only a short account of his paper, so that ample time will be available for discussion. Manuscripts in English or French must be received before May 1 . The maximum space for a paper is 2,500 words including formulæ and dia. grams, since the Proceedings must be limited to 500 pages. Preprints of all papers will be available at least a month in advance of the meeting. Owing to generous support from Dutch industry and scientific societies, the congress fee will be 15 florins (about $£ 18 s$. ); this will cover the cost of preprints, but not the Proceedings. The Organising Committee will help participants in obtaining accommodation at Scheveningen. The secretary of the Committee is Ir. H. C. den Daas, Julianalaan 134 (Postbox 66), Delft.

\section{Summer School in the Physics of Solids}

A Summer School in the Physics of Solids, with particular reference to the properties of ionic solids, will be held in the H. H. Wills Physical Laboratory of the University of Bristol during September 8-15. Lectures will be given by Prof. N. F. Mott, Dr. J. W. Mitchell and other members of the staff of the Laboratory. A purely theoretical course on the electrical properties of ionic solids was held in 1946. The present course is intended for members of the staffs of Government and industrial laboratories who wish to familiarize themselves with both experimental and theoretical work on the properties of ionic solids, particularly in fields beyond those with which they are directly concerned. For each branch of the subject, parallel lectures will be given on the experimental side and on the theoretical side. Accommoda. tion can be arranged at the University Hall of 
Residence, Clifton Hill House. Inquiries should be addressed to the Director of the Department of Adult Education, W. E. Salt, University, Bristol 8; completed application forms should be returned by June 15 .

\section{Summer School in Metal Physics}

A Summer School in Metal Physies will be held in the Cavendish Laboratory, Cambridge, during August 23-September 3. The School will provide an introduction to the application of physical methods to the examination and utilization of metals, and is intended for those whose researches require a more fundamentally physical approach than is usual in ordinary metallurgical and engineering practice. The lectures and demonstrations will deal with $(a)$ application of X-ray methods in the examination of metals, (b) physical and mechanical properties of metals. Both parts will be taken by all attending the School, and for Part $(\alpha)$ an elementary knowledge of X-ray diffraction methods and of crystal symmetry will be assumed. A detailed syllabus and form of application for admission can be obtained from G. F. Hickson, Secretary of the Board of Extra-Mural Studies, Stuart House, Cambridge, to whom the completed application form should be returned not later than June 1.

\section{University of London: Appointments}

THE following appointments in the University of London have been announced: Prof. A. C. Offord, professor of mathematics at King's College, Newcastle-upon-Tyne, since 1945, to the University chair of mathematics tenable at Birkbeck College as from October 1; Dr. R. E. M. Wheeler, director-general of archæology in India since 1944, to the chair of the archæology of the Roman Provinces tenable at the Institute of Archæology as from October 1; Miss Mary Barber, lecturer in bacteriology in the British Postgraduate Medical School, to the University readership in bacteriology tenable at St. Thomas's Hospital Medical School as from October 1; Dr. H. E. Rose, lecturer in mechanical engineering at King's College, to the University readership in mechanical engineering tenable at the College as from October 1 .

The following titles have been conferred : professor of geology in the University on Dr. Leonard Hawkes (Bedford College); reader in organic chemistry in the University on Dr. A. H. Cook (Imperial College of Science and Technology); reader in chemistry in the University on Dr. H. G. Poole (University College); reader in agricultural chemistry in the University on Dr. R. L. Wain (Wye College).

The degree of D.Sc. has been conferred on Franz Bergel (Lister Institute of Preventive Medicine).

\section{Colonial Service Appointments}

THE following appointments in the Colonial Service have been announced: J. L. Fleure, survey probationer, Malaya; R. W. Butler, veterinary officer, Tanganyika; R. M. S. Neave, veterinary officer, Kenya; D. Bradwell, analyst, Medical Department, Cyprus; R. L. Hartley, agricultural education officer, Fiji ; C. W. D. Kermode, assistant conservator of forests, Tanganyika; J. P. Oliver, agricultural officer, Falkland Islands ; L. Ross, assistant meteoro. logist, Nigeria ; A. J. Willis, assistant meteorologist, Nigeria; E. W. Leach (deputy director of agriculture, Trinidad), director of agriculture, Trinidad; J. C. Muir (director of agriculture, Trinidad), director of agriculture, Tanganyika; F. W. Toovey (principal research officer, Oil Palm Research Station, Nigeria), officer-in-charge, Oil Palm Research Station, Nigeria; H. Fraser (assistant conservator of forests, Tanganyika), senior assistant conservator of forests, Tanganyika; H. R. Herring (assistant conservator of forests, Tanganyika), senior assistant conservator of forests, Tanganyika; A. L. C. Thorne (veterinary officer, Gold Coast), veterinary education officer, Nigeria; J. Y. Moggridge (entomologist, Tsetse Research Department, Tanganyika), director, Tsetse Research Control Department, Tanganyika; H. C. Smith (senior assistant livestock officer, Tanganyika), livestock officer, Tanganyika; J. F. B. Watling (senior inspector of produce, Nigeria), principal produce inspector, Nigeria.

\section{New Satellite of Uranus}

IT is reported from the McDonald Observatory, Texas, that a new satellite of magnitude 17 to the planet Uranus was found on a plate taken on February 15, at the Cassegrain focus of the 82 -in. telescope. Two other plates taken on March 1 confirmed the new discovery. Its distance from the planet is about 0.00082 astronomical unit, or 76,500 miles, which implies that its period of revolution is about 31 hours.

\section{Acetylation of Sugars}

ReFerRiNe to the communication by S. D. Nicholas and Dr. F. Smith entitled "Acetylation of Sugars" (Nature, March 6, p. 349), Dr. P. H. Plesch, Chemistry Department, University of Manchester, remarks that the use of perchloric acid as catalyst in the acetylation of sugars is by no means new ; it has been discussed in some detail by D. Krueger and W. Roman (Berichte, 69, 1830 (1936) and Angew. Chem., 47, 58 (1934)).

\section{Announcements}

Mr. NorRIs E. DodD, Under-Secretary of Agriculture in the United States, has been appointed director-general of the United Nations Food and Agriculture Organisation, in succession to Sir John Boyd Orr, who has retired. The British Minister of Food has agreed to release Sir Herbert Broadley, deputy secretary, Ministry of Food, for appointment as deputy director general of the Organisation.

THE Fison Lectures of the Animal Health Trust will be delivered by Prof. L. Seekles, of the Veterinary Biochemical School of the University of Utrecht, at the Kingsway Hall, London, on May 10 and 12. He will discuss mineral disturbances in cattle, gastrointestinal autointoxication in cattle and horses, and conditional deficiencies of trace elements in cattle. Further particulars may be obtained from the Animal Health Trust, 232-235 Abbey House, Victoria Street, London, S.W.I.

The Ministry of Agriculture and Fisheries and the Department of Agriculture for Scotland propose to award, for the next academic year, a limited number of postgraduate scholarships in husbandry, agricultural economics, statistics and agricultural and dairy engineering. Particulars may be obtained from the Secretary, Ministry of Agriculture and Fisheries, 2 Cambridge Terrace, Regent's Park, London, N.W.1, or the Secretary, Department of Agriculture for Scotland, St. Andrew's House, Edinburgh 1.

Erratum. In the note on "American Summer Scholarships for European Students" (Nature, April 17, p. 593), it should have been stated that applicants must be less than thirty-five years of age. 